\title{
Predicting the potential distribution of aquatic herbaceous plants in oligotrophic Central Amazonian wetland ecosystems
}

\author{
Aline Lopes ${ }^{1,2 *}$ (1), Layon Oreste Demarchi ${ }^{2,3}$ (D), Augusto Cesar Franco ${ }^{1}$ (D), Aurélia Bentes Ferreira ${ }^{2,3}$ (D), \\ Cristiane Silva Ferreira ${ }^{1}$ (D), Florian Wittmann ${ }^{2,4}$ (D), Ivone Neri Santiago ${ }^{2}$ (D), Jefferson da Cruz ${ }^{2,5}$ (D), \\ Jeisiane Santos da Silva ${ }^{2,3}$ (D), Jochen Schöngart ${ }^{2,3}$ (D), Sthefanie do Nascimento Gomes de Souza ${ }^{2}$ (ㄷ) \\ and Maria Teresa Fernandez Piedade ${ }^{2,3}$ (1)
}

Received: May 25, 2020

Accepted: November 13, 2020

\begin{abstract}
Aquatic herbaceous plants are especially suitable for mapping environmental variability in wetlands, as they respond quickly to environmental gradients and are good indicators of habitat preference. We describe the composition of herbaceous species in two oligotrophic wetland ecosystems, floodplains along black-water rivers (igapó) and wetlands upon hydromorphic sand soils (campinarana) in the Parque Nacional do Jaú and the Reserva de Desenvolvimento Sustentável Uatumã in Central Amazonia, both protected areas. We tested for the potential distribution range (PDR) of the most frequent species of these ecosystems, which are the ones that occurred in at least two of the sampled wetlands, using species distribution models (SDMs). In total, 98 aquatic herbaceous species were recorded, of which 63 occurred in igapós and 44 in campinaranas. Most igapó species had ample PDRs across the Neotropics, while most campinaranas species were restricted to the Amazon Basin. These results are congruent with studies that described similar distribution patterns for tree and bird species, which emphasizes a high degree of endemism in Amazonian campinarana. However, we also found differences in the potential distribution of species between the two protected areas, indicating high environmental variability of oligotrophic ecosystems that deserve further investigation to develop effective measures for their conservation and protection.
\end{abstract}

Keywords: aquatic macrophytes, black-water floodplain, campinarana, igapó, SDMs, white-sand savannas

\section{Introduction}

Aquatic macrophytes are defined as "aquatic photosynthetic organisms, large enough to see with the naked eye, that actively grow permanently or periodically submerged below, floating on, or up through the water surface of inland freshwater or brackish waterbodies" (Chambers et al.
2008). In Amazonian river wetlands, where flood pulses are high (Junk et al. 1989), many herbaceous species have short life cycles and occur only during the low water (terrestrial phase). Their diaspores are well adapted to survive the subsequent inundation (aquatic phase). Therefore, these seemingly terrestrial plants are included in the group of aquatic herbaceous plants (Piedade et al. 2019). Aquatic herbaceous plants are highly diverse in terms of growth

1 Departamento de Botânica, Instituto de Ciências Biológicas, Universidade de Brasília, 70910-900, Brasília, DF, Brazil

2 Instituto Nacional de Pesquisas da Amazônia, Ecologia, Monitoramento e Uso Sustentável de Áreas Úmidas, 69067-375, Manaus, AM, Brazil

3 Programa de Pós-graduação em Botânica, Instituto Nacional de Pesquisas da Amazônia, 69067-375, Manaus, AM, Brazil

4 Karlsruhe Institute for Technology, Institute for Geography and Geoecology, Department of Wetland Ecology, 76437, Rastatt,

Baden-Württemberg, Germany

5 Laboratório de Taxonomia Vegetal, Universidade Federal do Amazonas, 69080-900, Manaus, AM, Brazil

* Corresponding author: alopesmga@gmail.com 
forms (i.e., immersed, submerged floating plants, with floating leaves, epiphytic, among others), which are closely associated to differences in resource capture, allocation, stress tolerance and survival strategies (Piedade et al. 2019). This ensures rapid population recovery from disturbance and successfull colonization of highly dynamic environments that are subjected to seasonal oscillations of the water level and abrupt transitions in the environmental conditions along the topographic gradient (Murphy et al. 2019; Piedade et al. 2019). Aquatic herbaceous plants are also especially suitable for mapping environmental variability in wetlands, being sensitive to both long- and short-term changes in environmental conditions (Lacoul \& Freedman 2006).

According to international criteria of wetland definition, wetlands in the Amazon Basin cover an area of more than two million square kilometers, including areas that are seasonally flooded by lateral river overflows and those that are episodically waterlogged by oscillating groundwater levels (Junk et al. 2014). Floodplains along large rivers in Amazon Basin cover an area of approximately $750,000 \mathrm{~km}^{2}$ and are divided in environments with fertile conditions (white-water floodplains, called várzea with about $450,000 \mathrm{~km}^{2}$ extension) and floodplains of low to intermediate fertility (black- and clear-water floodplains, called igapó, with approximately $300,000 \mathrm{~km}^{2}$ extension) (Melack \& Hess 2010; Wittmann \& Junk 2016). Igapó and várzea floodplains are influenced by a monomodal flood-pulse with amplitudes averaging about $10 \mathrm{~m}$ in the Central Amazon region, inducing a distinct seasonality (aquatic and terrestrial phases) in the floodplains (Junk et al. 1989). Besides nutrient contents of waters and soils, the floodplains are influenced by the duration of the aquatic phase, resulting in a distinct flora of herbaceous (Piedade et al. 2010) and tree communities (Wittmann et al. 2012) that can be inundated for periods of more than six months per year. The herbaceous communities in várzea and igapó are distinct with low floristic similarity (Lopes et al. 2019). Because environmental conditions such as water transparency and nutrient contents may vary significantly between rivers, floristic inventories also show a low similarity between the igapó of clear- and black-water rivers (Crema 2017). In contrast, the campinaranas cover an area of 334,879 $\mathrm{km}^{2}$ in the Amazon region (Adeney et al. 2016) and occur on nutrient-poor sandy soils. The presence of impermeable soil layers near the surface, in hydromorphic campinaranas, results in low drainage and saturation of the soil during the rainy seasons. However, only in some areas the water column rises a few centimeters above the soil surface, and the effects of flooding or waterlogging are mostly restricted to the plant root system (Anderson 1981; Franco \& Dezzeo, 1994; Coomes 1997; Junk et al. 2011; Damasco et al. 2013; Adeney et al. 2016). In many regions, as along the lower Negro river, the distribution of these ecosystems is fragmented within the forest matrix (Prance 1996).

Studies on species composition and distribution of Amazonian aquatic plants are still scarce considering that wetlands occupy about $30 \%$ of the region (Junk et al. 2011). Near the city of Manaus (State of Amazonas, Brazil) Junk \& Piedade $(1993 ; 1994)$ conducted studies with a large sample effort and recorded 388 species of aquatic, terrestrial and semiaquatic herbaceous species for the várzea. Herbaceous species in black-water igapós of different regions in the Central Amazon were less numerous and so far a total number of 178 species has been recorded (Lopes et al. 2019), while only 52 species were recorded in clear-water igapós in Colombian Guiana (Atuesta-Ibargüen 2019), and 49 species in clear-water igapós of the Tapajós river (Pará, Brazil) (Crema 2017). Inventories of herbaceous species in white-sand ecosystems (campinarana) at the Parque Nacional do Viruá (Northern Amazon) and Acre State (Southwestern Amazon) reported 196 (Costa et al. 2016) and 110 species (Daly et al. 2016), respectively. Both nutrient-poor campinarana and black-water igapó are thought to harbor several endemic species adapted to these harsh and extreme environments (Kubitzki 1989; Wittmann et al. 2010). More knowledge on the composition of aquatic herbaceous species and the factors that influence their distribution in these oligotrophic environments is needed to understand the functioning of these ecosystems and in order to contribute to the development of effective conservation and management strategies.

Historical climatic factors could influence the current distribution pattern of aquatic plants but are rarely considered in studies of aquatic vegetation distribution (Lopes et al. 2017; Murphy et al. 2019). Although each species has its own distribution range, repetitive patterns of distribution are common (Marchioretto et al. 2004); while some distribution ranges reflect connections to past climates, others indicate limits imposed by the present environment (Gomes et al. 2020). The use of modeling to predict species distribution allows to evaluate both, the current characteristics of the environment and to simulate the distribution in paleo-, present, and future climates. It also allows gaining insights on how species would respond to physiological stressors and to changing environments under rising $\mathrm{CO}_{2}$ and global warming (Pecchi et al. 2019; Santana Jr. et al. 219; Zhang et al. 2019).

The objectives of this study were: (1) to determine the composition of aquatic herbaceous plants in black-water igapó floodplains and hydromorphic campinarana ecosystems of two PELD-MAUA sites (Brazilian Long-term Ecological Research Network - Ecology, monitoring and sustainable use of wetlands) located in the protect areas Parque Nacional do Jaú (JNP) and Reserva de Desenvolvimento Sustentável Uatumã (USDR), (2) to compare them with the flora of other Brazilian wetland ecosystems and (3) by using species distribution models (SDMs), to estimate the potential distribution range (PDR) within the Neotropical region for the 10 most frequent species in each ecosystem, as well as for the five shared species between ecosystems. We hypothesized that the potential distribution ranges of blackwater igapó species are much wider (i.e., Neotropical) than 
those of campinarana species (i.e., restricted to the Amazon basin), because the latter occur in insular and fragmented habitats interspersed within the Amazonian rainforest. On the other hand, in the black-water igapó floodplain the water connectivity would allow a more effective and widespread dispersion. In this regard, we also expected that the campinarana would share fewer species with other Brazilian wetlands than the igapó.

\section{Materials and methods}

The PELD-MAUA sites are established in the Parque Nacional do Jaú (JNP) and the Reserva de Desenvolvimento Sustentável Uatumã (USDR) in the Central Amazon basin, with focus on the oligotrophic wetland vegetation of blackwater igapó (from now on, when referring to the study areas, called just igapó) and campinarana. The main objective of the PELD-MAUA project is to monitor changes in vegetation in the background of ongoing climate and land-use changes. The distance between both PELD-sites is approximately $300 \mathrm{~km}$.

Reserva de Desenvolvimento Sustentável Uatumã USDR

The USDR is located $150 \mathrm{~km}$ northeast of Manaus city, shared by the municipalities of Itapiranga and São Sebastião do Uatumã (State of Amazonas). The USDR covers an area of
$4,244 \mathrm{~km}^{2}$ of terra-firme forests, igapós, and campinaranas. The PELD site is located at $02^{\circ} 10^{\prime} 30^{\prime \prime}-02^{\circ} 11^{\prime} 30^{\prime \prime} \mathrm{S}$ and $59^{\circ} 00^{\prime} 30^{\prime \prime}-59^{\circ} 01^{\prime} 30^{\prime \prime}$ W (Fig. 1). The USDR is cut by the Uatumã river through its entire extension. The climate is tropical humid, with a pronounced rainy season from November to May and a dry season from June to October, with mean annual temperature of $27^{\circ} \mathrm{C}$ and mean annual precipitation of 2,376 $\mathrm{mm}$ (IDESAM 2009). The flood pulse is monomodal; however, after the construction of the Balbina dam, flooding is regulated by the opening and closing of the floodgates (Assahira et al. 2017), depending on the level of the water reservoir and the demand for power generation.

The USDR consists of different forested ecosystems. The largest part of the territory is covered by dense, non-flooded upland forests (terra-firme) on plateaus at a maximum altitude of approximately $130 \mathrm{~m}$ a.s.l.. The white-sand vegetation (campinarana) of USDR occurs as "islands" in terrain depressions (at approximately $40 \mathrm{~m}$ a.s.l.) scattered throughout the terra-firme forest, and show great heterogeneity in the vegetation physiognomy due to the variations of the soil nutrients and flooding (Targhetta et al. 2015). The open campinarana physiognomies are dominated by shrubs, small trees, and a conspicuous herbaceous component. The orchid Sobralia granitica G.A.Romero \& Carnevali, the fern Actinostachys pennula (Sw.) Hook. and several species of Eriocaulaceae, Cyperaceae and Xyridaceae characterize the herbaceous vegetation. In campinaranas

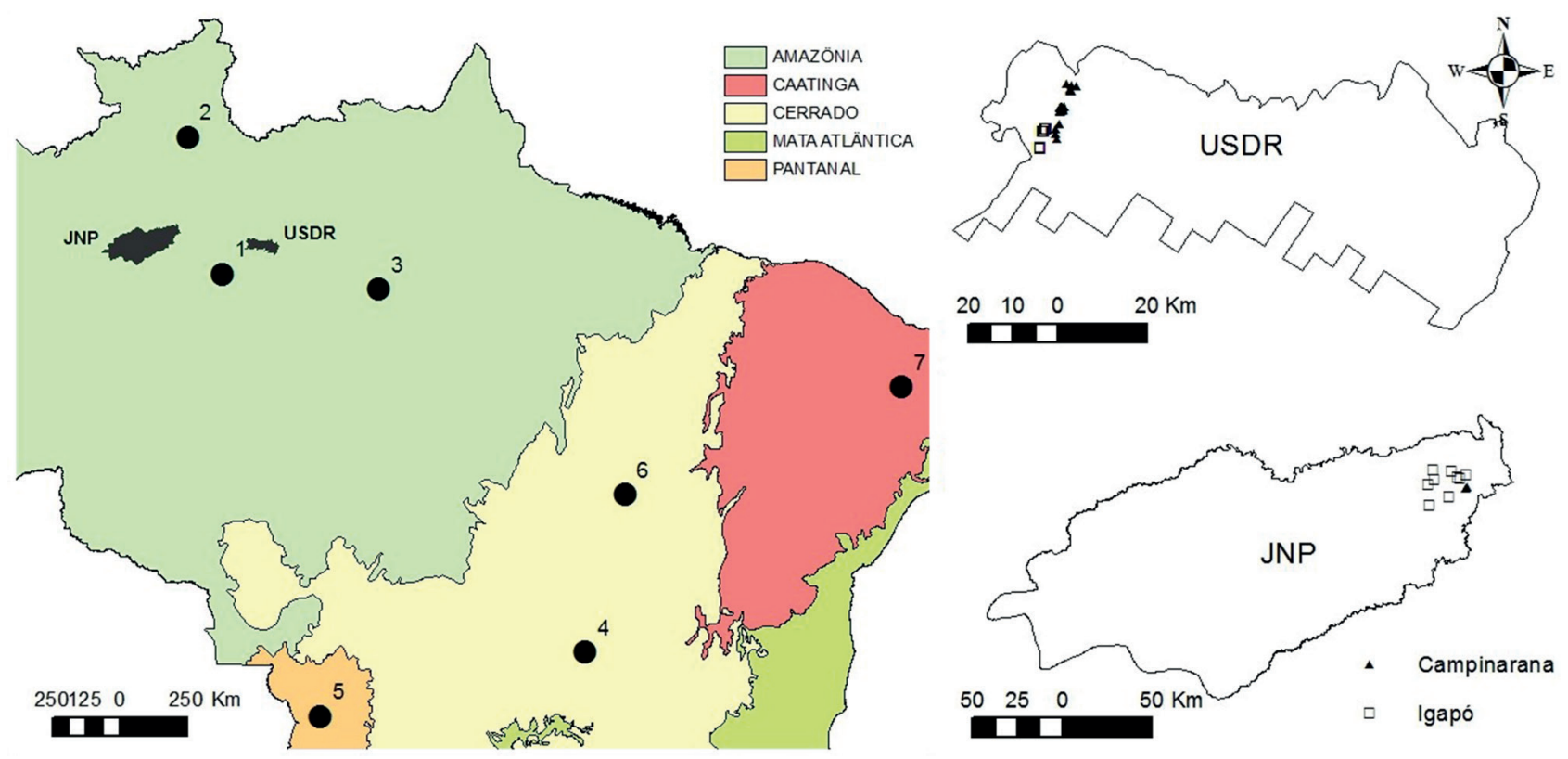

Figure 1. Wetlands (campinarana and igapó) inventoried in Parque Nacional do Jaú (JNP) and Reserva de Desenvolvimento Sustentável Uatumã (USDR) and location of data from Brazilian wetland inventories: 1) Amazonian várzea floodplains, 257 spp. (Junk \& Piedade 1993); 2) campinaranas of Parque Nacional do Viruá (VNP) in Roraima State, 193 species (Costa et al. 2016); 3) clear-water igapó of Tapajós River of Pará State, 49 spp. (Crema 2017); 4) wetlands in the savanna biome, gallery forest (516 spp.), campo limpo úmido (42 spp.), campo úmido (108 spp.), campo sujo com murundus (16 spp.), campo limpo de murundus (40 spp.), campo com murundus (59 spp.), vereda (65 spp.) of the Distrito Federal (Chacon et al. 2015); 5) several wetlands in the Pantanal of Mato Grosso and Mato Grosso do Sul States, 214 spp. (Pott \& Pott 1997); 6) wetlands in the savanna biome, vereda, 201 ssp. (Silva et al. 2018) and 7) water bodies of semi-arid Caatinga biome of Paraiba State, 121 spp. (Torres et al. 2016). 
where the arboreal component dominates species richness increases, and the canopy becomes stratified (Fig. 2A).

Black-water floodplain forests (igapó) with a distinct zonation of tree species along the flood-level gradient dominate along the main-river channel and oxbow lakes of the Uatumã river (approximately $25 \mathrm{~m}$ a.s.l; Targhetta et al. 2015). The low igapó is flooded by up to 265 days per year on average and the alternation between the terrestrial and aquatic phase determines the dynamics of the annual herbaceous plants. With increasing topography, igapó forests become more complex and the herbaceous component becomes predominantly composed of perennial species restricted to the forest understory. At intermediate and high topographies flooding duration ranges from about 100 to 150 days and less than 50 days per year, respectively (Fig. 2B). The vegetation of the black-water igapó of the Uatumã river was subject to several disturbances due to the construction of the Balbina dam, whose consequences are summarized in Assahira et al. 2017; Lobo et al. 2019 and Rocha et al. 2019.

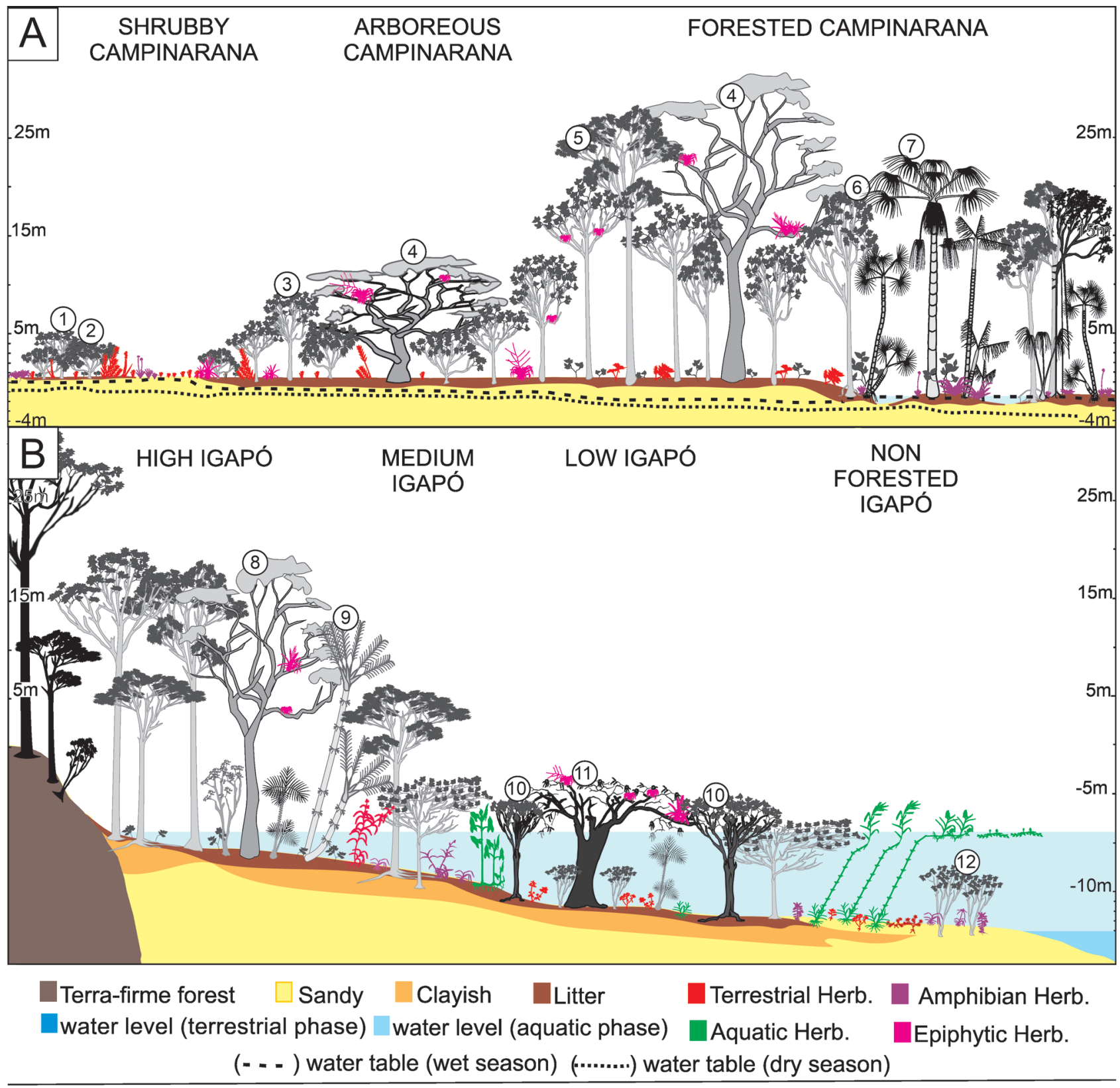

Figure 2. Generic schematic profiles of vegetation structure and some examples of herbaceous life forms in the collection areas. A) Campinaranas and B) Igapós. The length and sequence of the physiognomies, as well as the distance from the water table in the dry / rainy season (in the campinaranas) and the water levels in the terrestrial / aquatic phase vary from area to area both in the USDR and in JNP. Characteristic woody species: 1 . Humiria balsamifera; 2. Ilex divaricata; 3. Pradosia schomburgkiana; 4 . Aldina heterophylla; 5. Sterigmapetalum plumbeum; 6. Tovomita calophyllophylla; 7. Mauritia carana; 8. Aldina latifolia; 9. Astrocaryum jauari; 10. Eschweilera tenuifolia; 11. Macrolobium acaciifolium; 12. Eugenia inundata. 
Both black-water igapó and campinarana ecosystems are characterized by nutrient-poor soils of comparatively high acidity. Soil texture in the campinarana plots is homogeneously sandy, whereas the igapó plots had more variable textures, with predominance of silt and clay soils (Targhetta et al. 2015). Despite both campinarana and igapó soils being poor in nutrients, exchangeable bases, C, N, P, $\mathrm{K}$ in the igapó were two to three-fold higher than those in the campinarana and 10-fold for Fe (Targhetta et al. 2015).

Parque Nacional do Jaú - JNP

The JNP is located $220 \mathrm{~km}$ northwest of the city of Manaus in the municipalities of Barcelos and Novo Airão of the Amazonas State, and covers an area of approximately $22,720 \mathrm{~km}^{2}$. The PELD site is established at the coordinates $01^{\circ} 54^{\prime}-01^{\circ} 57^{\prime} S$ and $61^{\circ} 27^{\prime}-61^{\circ} 28^{\prime} \mathrm{W}$ (Fig. 1). Mean annual temperature is $26.7^{\circ} \mathrm{C}$, and mean annual precipitation amounts to $2,300 \mathrm{~mm}$. The rainy season occurs from December to May and the dry season from June to September. The flooding cycle is monomodal, with a mean annual amplitude of $8.17 \mathrm{~m}$; highest water levels occur in June and July, and lowest in October and November (Ferreira 2000). The soil is derived from ancient tertiary sediments, with high levels of kaolinitic clay and large areas covered by white sands (podzols) (Junk et al. 2015).

The JNP is also mostly covered by terra-firme forest with some isolated campinaranas. As in the USDR, campinaranas present a heterogeneous vegetation mosaic. In open areas, shrubs and herbs predominate, particularly Everardia montana Ridl., Duckea squarrosa (Willd. ex Link) Maguire and many species of Eriocaulaceae, Xyridaceae, Lentibulariaceae, among others. The forest physiognomies alternate between stratified forests with emergent trees of approximately $20 \mathrm{~m}$ height to very dense forests with trees reaching heights of 5-8 $\mathrm{m}$ (Fig. 2A).

Igapó forests dominate along the Jaú river and show the typical zonation of tree species along the flood-level gradient. The lowest levels of the flood-level gradient are covered with monodominant formations of the tree Eschweilera tenuifolia (O.Berg) Miers. With increasing topography, tree diversity increases to up to 70 species per hectare $(>10 \mathrm{~cm}$ diameter at breast height) (Fig. 2B). The herbaceous component predominates at the lower topographies, being restricted to the forest understory at higher topographic positions. When compared to the igapó of the USDR, it presents higher richness of tree species, however during the last decades it has been suffering from large-scale anthropogenic fires (PELD MAUA data unpublished).

\section{Field sampling design}

In the igapó plots have been established in both forested and non-forested areas. In forested areas, three 1-ha plots were installed along the flood-level gradient on: (1) high ( $<50$ days of inundation year $\left.{ }^{-1}\right),(2)$ intermediate (100-150 days of inundation year ${ }^{-1}$ ), and (3) low topographies (>265 days of inundation year ${ }^{-1}$ ) (Lobo et al. 2019). Within each plot three transects of $25 \times 2 \mathrm{~m}\left(50 \mathrm{~m}^{2}\right)$ were established to inventory all herbaceous plants in densely forested areas. For the inventory of herbaceous vegetation in non-forested areas, nine transects of $25 \times 2 \mathrm{~m}\left(50 \mathrm{~m}^{2}\right)$ were installed. To inventory herbaceous plants of the hydromorphic campinaranas in the USDR (Targhetta et al. 2015), nine plots of $5 \times 5 \mathrm{~m}\left(25 \mathrm{~m}^{2}\right)$ were installed. Distances between plots in the same ecosystem ranged from $0.5-3.5 \mathrm{~km}$, while average distance of plots between igapó and campinarana was approximately $6 \mathrm{~km}$. Herbaceous plants were identified to the lowest taxonomic level possible. The scientific names were verified according to Flora do Brasil 2020 (Forzza et al. 2020) following the APG IV (Angiosperm Phylogeny Group, 2009) system by the $R$ 3.6.1 program (R Development Core Team, 2020) and the flora package (https://CRAN.R-project.org/package=flora). Fertile specimens were deposited at the INPA Herbarium, and sterile specimens were archived at the herbarium of the INPA-MAUA Group. For the analysis of species composition, we used the presence of species per plot, ecosystem (igapó and campinarana) and site (JNP and USDR).

\section{Potential Distribution Range - PDR}

For the analysis of species distribution, we selected the five most frequent species on plot level in each inventoried igapó and campinarana at each site and five species that were found in at least two of the four inventoried sites (total of 25 herbaceous species). Georeferenced data gathered from the examination of specimens from CRIA herbaria (CRIA 2020) and GBIF (Global Biodiversity Information Facility, 2020) were used. The data were standardized, and duplicates excluded.

To estimate and map the potential distribution of these species we started with gridded data sets at $10 \mathrm{~km} \times 10 \mathrm{~km}$ resolution of 41 variables, including bioclimatic variables, vegetation cover, and soil nutrients as predictors (Tab. S1 in supplementary material). A principal component analysis (PCA) was performed with these variables to eliminate collinearity between predictor variables and for controlling the overfitting of models (Guisan \& Zimmermann 2000; Dormann et al. 2013). The PCA axes that added up $90 \%$ of the variation within the Neotropical region were used as predictor variables. We utilized the rasterPCA function of the RStoolbox package (Leutner et al. 2017) in R 4.2.0 (R Development Core Team 2020).

We used eight algorithms offered in the BIOMOD2 package (Thuiller et al. 2019) to generate SDMs, categorized as 1) one regression method (Generalized Linear Models GLM (McCullagh \& Nelder 1989)); 2) four machine-learning or complex methods (Artificial Neural Networks - ANN (Hopfield 1982), Generalized Boosted Models - GBM (Friedman et al. 2000), Maximum Entropy - MaxEnt (Phillips et al. 2006) and Random Forests - RF (Breiman 1999)); 3) two classification methods (Classification Tree Analysis CTA (Breiman et al. 1984), Flexible Discriminant Analysis - FDA (Hastie et al. 1994)); 4) Surface Range Envelope - SRE 
model, very similar to Bioclim (Jiguet et al. 2011). The $\mathrm{R}$ script was prepared by Pedro V. Eisenlohr (https://github. com/pedroeisenlohr/niche_modelling).

Because our data consisted of species presence records only, we generated pseudo-absence (background) points, sampled across the study area. When fitting models CTA, $\mathrm{RF}$, and GBM we generated as many pseudo-absence points as our species distribution records, whereas for models ANN, SRE, FDA, GLM, and MAXENT we used 1,000 pseudoabsence points (Barbet-Massin et al. 2012). In both cases, we produced 10 replicates of pseudoabsence data and used $70 \%$ of the species presence data to fit models and $30 \%$ to assess model accuracy, repeating this process 10 times.

As suggested by Brown \& Yoder (2015) the true skill statistic (TSS) (Allouche et al. 2006) was used as a filter for algorithms with number of occurrences above nine. TSS values range from -1 to 1 , where 0 indicates no predictive power. The algorithms with TSS $\leq 0.4$ were excluded from the final consensus model, because of their low accuracy (Allouche et al. 2006; Zhang et al. 2015). The remaining algorithms were used to produce a combined projection or consensus map (Araújo \& New 2007). This technique consists in generating a consensus model, based on binary maps of each algorithm chosen, where areas of high suitability will be those that most models have indicated as being prone to the occurrence of the species (Giannini et al. 2012).

To quantify the uncertainty among the eight different models and the consensus models we calculated the mean, standard deviation and coefficient of the uncertainty measures that BIOMOD2 provides: sensitivity-probability that a test result will be positive when the species is present (true positive rate, expressed as a percentage); specificityprobability that a test result will be negative when the species is not present (true negative rate, expressed as a percentage); and the cutoff point (Thuiller et al. 2019). We classified the consensus model generated for each species based on the values of mean sensitivity and sensitivity standard deviation (SD). Better-performing methods have sensitivities close to one hundred. We assigned an overall category of robustness or reliability adapted from Ochoa-Ochoa et al. (2016): poor (sensitivity $\leq 50$ or $S D \geq 50$ ), medium (sensitivity $\geq 50$ with $S D \leq 45$ ), good (sensitivity $\geq 70$ with $S D \leq 30$ ) and optimum (sensitivity $\geq 90$ with $\mathrm{SD} \leq 30$ ).

We used the consensus map to generate the final potential distribution range (PDR) map. The PDR had a range of values from 0 to 100 which were regrouped into four classes of potential habitats: "high potential" $(>60)$, "good potential" (40-60), "moderate potential" (20-40) and "least potential" $(<20)$. Potential distribution maps were created by ArcGIS Software 9.0 (Esri 2013) for the Neotropical region, Amazon basin, JNP, and USDR. We used the data collected in JNP and USDR (which did not enter the model) to verify that the consensus model was also able to predict the occurrence of the selected species in these protected areas.

\section{Species Similarity to other Brazilian Wetlands}

To test the hypothesis that campinaranas share fewer species with the black-water igapó surveyed (JNP and USDR) and other Brazilian wetland ecosystems, we compared our floristic data with herbaceous species inventories (Junk \& Piedade 1993; Silva et al. 2018; Chacon et al. 2015; Pott \& Pott 1997; Costa et al. 2016; Torres et al. 2016; Crema 2017) from other locations (Fig. 1, Tab. 1), after updating the synonyms by Flora do Brasil 2020 (Forzza et al. 2020). We calculated the level of similarity using Jaccard's index $J$ $=c /(a+b-c)$, where $a$ is the number of species in region 1 , $b$ is the number of species in region 2 , and $c$ is the number of shared species between both regions. $J$-index ranges between zero and one, indicating complete dissimilarity and similarity, respectively. To recognize characteristic floristic groups, we constructed a phenogram using an unweighted pair-group procedure (UPGMA) from the similarity matrix. UPGMA uses arithmetical averaging between the similarity indices of different groups. For cluster recognition in the phenogram, we conducted bootstrapping on the species-area matrix, using 5000 interactions and recomputing Jaccard's index among different sites in each calculation.

\section{Results}

A total of 98 aquatic herbaceous species were found belonging to 32 families (Tab. S2 in supplementary material). At JNP we recorded 33 species in the igapó and 10 species in the campinarana, being four of them present in campinarana and igapó (Everardia montana, Miconia subsimplex, Ischnosiphon cannoideus and Trichomanes martiusii. In the USDR we recorded 30 species in the igapó and 34 species in the campinarana, with no species found in the two ecosystems. The igapós of JNP and USDR shared four species (Utricularia foliosa, Oryza grandiglumis, Montrichardia arborescens and Tassadia trailiana). Only Trichomanes martiusii occurred in the campinaranas of both study regions and in the igapó of JNP (Tab. S2 in supplementary material). Thus, we selected the species E. montana, M. subsimplex, U. foliosa, O. grandiglumis and T. martiusii for the elaboration of PDRs.

Overall, the families with the highest number of species were Cyperaceae (17 spp.), Poaceae (14 spp.), Orchidaceae (seven spp.), Marantaceae (six spp.) and Eriocaulaceae (five spp.). In the campinaranas of JNP, Xiridaceae was the most speciose family with 3 spp. and the Orchidaceae (seven spp.) in the USDR. Cyperaceae (eight spp.) and Poaceae (eight spp.) were the most species-rich families at JNP and USDR, respectively. Four species were listed in the IUCN Red List of Threatened Species (IUCN 2020), three being classified as LC (least-concern), Alternanthera paronychioides, Utricularia foliosa, Schizaea elegans, and Voyria aphylla as DD (data deficient). Our inventory includes the first record of Evolvulus genistoides in the Amazon region, which, according 
to Flora do Brasil 2020 (Forzza et al. 2020), occurs in the States of Espírito Santo, Minas Gerais and Rio de Janeiro. No species is considered invasive according to the Brazil National Invasive Alien Species Database (Instituto Hórus, institutohorus.org.br). Oryza rufipogon with origin from Asia and Digitaria ciliaris, originally from Asia and Africa are considered naturalized according to the Brazilian Flora.

Few species were shared among JNP and USDR and other Brazilian herbaceous wetland inventories (Pott \& Pott 1997; Junk \& Piedade 1993; Chacon et al. 2015; Costa et al. 2016;
Silva et al. 2018). The igapó of JNP showed flora composition closely related with the Central Amazonian várzea and the campinarana of the Parque Nacional do Viruá (VNP) with eight and seven species in common, respectively. However, the campinarana of the JNP only shared three species with the same ecosystem at the VNP. The igapó at USDR had 19 species found in the várzea and eight in the campinarana of the VNP, while the campinarana of the USDR shared only two species with the same ecosystem at the VNP (Tab. 1).

Table 1. Presence of herbaceous species in the wetlands (campinarana and igapó) inventoried in Parque Nacional d Jaú (JC= Jaú campinarana, JI= Jaú igapó) and Reserva de Desenvolvimento Sustentável Uatumã (UC= Uatumã campinarana, UI= Uatumã igapó) and other Brazilian wetland inventories: 1) Amazonian várzea floodplains (Junk \& Piedade 1993); 2) campinaranas of Parque Nacional do Viruá (Costa et al. 2016); 3) clear-water igapó of Tapajos River (Crema 2017); 4) wetlands in the savanna biome, gallery forests (4A), campo limpo úmido (4B), campo úmido (4C), campo sujo com murundus (4D), campo limpo de murundus (4E), campo com murundus (4F) and vereda (4G) (Chacon et al. 2015); 5) Pantanal (Pott \& Pott 1997); 6) wetlands in the savanna biome (Cerrado), vereda (Silva et al. 2018); 7) semi-arid Caatinga (Torres et al. 2016).

\begin{tabular}{|c|c|c|c|c|c|c|c|c|c|c|c|c|c|c|c|c|c|}
\hline Species & $\mathrm{Jl}$ & JC & UI & UC & 1 & 2 & 3 & $4 \mathrm{~A}$ & 4B & 4C & 4D & 4E & $4 F$ & $4 G$ & 5 & 6 & 7 \\
\hline Abolboda grandis Griseb. & & $\mathrm{X}$ & & & & & & & & & & & & & & & \\
\hline Aciotis ornata (Miq.) Gleason & $\mathrm{X}$ & & & & & & & & & & & & & & & & \\
\hline Acroceras zizanioides (Kunth) Dandy & & & $\mathrm{X}$ & & $\mathrm{x}$ & & & & & & & & & & $\mathrm{X}$ & & \\
\hline Actinostachys pennula (Sw.) Hook. & & & & $\mathrm{X}$ & & & & & & & & & & & & & \\
\hline Aechmea huebneri Harms & & & & $\mathrm{X}$ & & & & & & & & & & & & & \\
\hline Alternanthera paronychioides A.St.-Hil. & & & $\mathrm{X}$ & & $\mathrm{X}$ & & & & & & & & & & & & \\
\hline Bacopa egensis (Poepp.) Pennell & & & $\mathrm{X}$ & & & $\mathrm{X}$ & & & & & & & & & $\mathrm{X}$ & & \\
\hline Bifrenaria longicornis Lindl. & & & & $\mathrm{X}$ & & & & & & & & & & & & & \\
\hline Brassavola martiana Lindl. & & & & $\mathrm{X}$ & & & & & & & & & & & & & \\
\hline Bromelia tubulosa L.B.Sm. & & & & $\mathrm{X}$ & & & & & & & & & & & & & \\
\hline Bulbostylis junciformis (Kunth) C.B.Clarke & & & & $\mathrm{X}$ & & $\mathrm{X}$ & & & & & & & & & & $\mathrm{X}$ & \\
\hline Catasetum ciliatum Barb.Rodr. & & & & $\mathrm{X}$ & & & & & & & & & & & & & \\
\hline Comanthera kegeliana (Körn.) Moldenke & & & & $\mathrm{X}$ & & & & & & & & & & & & & \\
\hline Croton dissectistipulatus Secco & & & & $\mathrm{X}$ & & & & & & & & & & & & & \\
\hline Cuphea annulata Koehne & & & & $\mathrm{X}$ & & & & & & & & & & & & & \\
\hline Cyperus aggregatus (Willd.) Endl. & & & $\mathrm{X}$ & & $\mathrm{X}$ & $\mathrm{X}$ & & & & & & & & & & & \\
\hline Cyperus distans $\mathrm{L}$. & & & $\mathrm{X}$ & & $\mathrm{x}$ & & & & & & & & & & & & $\mathrm{X}$ \\
\hline Digitaria ciliaris (Retz.) Koeler & & & $\mathrm{X}$ & & $\mathrm{X}$ & & & & & & & & & & & & \\
\hline Diplasia karatifolia Rich. ex Pers. & $\mathrm{x}$ & & & & & & & & & & & & & & & & \\
\hline Duckea squarrosa (Willd. ex Link) Maguire & & $\mathrm{X}$ & & & & $\mathrm{X}$ & & & & & & & & & & & \\
\hline Echinochloa polystachya (Kunth) Hitchc. & & & $\mathrm{X}$ & & $\mathrm{X}$ & & $\mathrm{X}$ & & & & & & & & $\mathrm{X}$ & & $\mathrm{X}$ \\
\hline Eleocharis minima Kunth & $\mathrm{x}$ & & & & & & $\mathrm{X}$ & $\mathrm{X}$ & & & & & & & $\mathrm{X}$ & & \\
\hline Encyclia mapuerae (Huber) Brade \& Pabst & & & & $\mathrm{X}$ & & & & & & & & & & & & & \\
\hline Epidendrum orchidiflorum (Salzm.) Lindl. & & & & $\mathrm{X}$ & & $\mathrm{X}$ & & & & & & & & & & & \\
\hline Erechtites hieracifolius (L.) Raf. ex DC. & & & $\mathrm{X}$ & & $\mathrm{X}$ & & & & & & & & & & & $\mathrm{X}$ & $\mathrm{X}$ \\
\hline Euploca filiformis (Lehm.) J.I.M.Melo \& Semir & & & $\mathrm{X}$ & & $\mathrm{X}$ & & & & & & & & & & & & \\
\hline Everardia montana Ridl. & $\mathrm{X}$ & $\mathrm{X}$ & & & & & & & & & & & & & & & \\
\hline Evolvulus genistoides Ooststr. & & & & $\mathrm{X}$ & & & & & & & & & & & & & \\
\hline Fimbristylis aestivalis Vahl & & & $\mathrm{X}$ & & & & & & & & & & & & & & \\
\hline Fimbristylis miliacea (L.) Vahl & & & $\mathrm{X}$ & & $\mathrm{X}$ & & & & & & & & & & & & \\
\hline Fimbristylis vahlii (Lam.) Link & & & $\mathrm{X}$ & & & $\mathrm{X}$ & & & & & & & & & & & $\mathrm{X}$ \\
\hline Goeppertia acuminata (Steyerm.) Borchs. \& S. Suárez & & & & $\mathrm{X}$ & & & & & & & & & & & & & \\
\hline Guadua ciliata Londoño \& Davidse & $\mathrm{X}$ & & & & & & & & & & & & & & & & \\
\hline Hymenachne amplexicaulis (Rudge) Nees & $\mathrm{X}$ & & & & $\mathrm{X}$ & & $\mathrm{X}$ & & & & & & & & $\mathrm{X}$ & & $\mathrm{X}$ \\
\hline Hypolytrum longifolium (Rich.) Nees & $\mathrm{X}$ & & & & & & & & & & & & & & & & \\
\hline Hyptis atrorubens Poit. & $\mathrm{X}$ & & & & & & & & & & & & & & & & \\
\hline Hyptis parkeri Benth. & & & $\mathrm{X}$ & & $\mathrm{X}$ & & & & & & & & & & & & \\
\hline Ipomoea rubens Choisy & $\mathrm{X}$ & & & & & & & & & & & & & & $\mathrm{X}$ & & \\
\hline
\end{tabular}


Table 1. Cont.

\begin{tabular}{|c|c|c|c|c|c|c|c|c|c|c|c|c|c|c|c|c|c|}
\hline Species & $\mathrm{J}$ & JC & UI & UC & 1 & 2 & 3 & $4 \mathrm{~A}$ & 4B & 4C & 4D & 4E & $4 F$ & 46 & 5 & 6 & 7 \\
\hline Irlbachia poeppigii (Griseb.) L.Cobb \& Maas & $\mathrm{X}$ & & & & & & & & & & & & & & & & \\
\hline Ischnosiphon cannoideus L.Andersson & $\mathrm{X}$ & $\mathrm{X}$ & & & & & & & & & & & & & & & \\
\hline Ischnosiphon leucophaeus (Poepp. \& Endl.) Körn. & & & & $\mathrm{x}$ & & & & & & & & & & & & & \\
\hline Ischnosiphon polyphyllus (Poepp. \& Endl.) Körn. & $\mathrm{X}$ & & & & $\mathrm{X}$ & & & & & & & & & & & & \\
\hline Justicia comata (L.) Lam. & & & $\mathrm{X}$ & & $\mathrm{X}$ & & & & & & & & & & & & \\
\hline Lagenocarpus rigidus Nees & & & $\mathrm{X}$ & & & $\mathrm{X}$ & & & & $\mathrm{X}$ & $\mathrm{X}$ & & & $\mathrm{X}$ & & $\mathrm{X}$ & \\
\hline Lepidaploa arenaria (Mart. ex DC.) H.Rob. & & & & $\mathrm{x}$ & & & & & & & & & & & & & \\
\hline Lindsaea schomburgkii Klotzsch & & & & $\mathrm{X}$ & & & & & & & & & & & & & \\
\hline Ludwigia erecta (L.) H.Hara & & & $\mathrm{X}$ & & & & & & & & & & & & & & $\mathrm{X}$ \\
\hline Ludwigia hyssopifolia (G.Don) Exell & $\mathrm{X}$ & & & & & $\mathrm{X}$ & & & & & & & & & & & \\
\hline Miconia calvescens DC. & $\mathrm{X}$ & & & & & & & $\mathrm{x}$ & & & & & & & & & \\
\hline Miconia subsimplex Pilg. & $\mathrm{X}$ & $\mathrm{X}$ & & & & & & & & & & & & & & & \\
\hline Montrichardia arborescens (L.) Schott & $\mathrm{X}$ & & $\mathrm{X}$ & & $\mathrm{X}$ & $\mathrm{X}$ & $\mathrm{X}$ & & & & & & & & & & \\
\hline Neoregelia eleutheropetala (Ule) L.B.Sm. & & & & $\mathrm{X}$ & & & & & & & & & & & & & \\
\hline Olyra longifolia Kunth & $\mathrm{X}$ & & & & & & & & & & & & & & & & \\
\hline Oryza glumaepatula Steud. & $\mathrm{X}$ & & & & & & $\mathrm{X}$ & & & & & & & & $\mathrm{X}$ & & \\
\hline Oryza grandiglumis (Döll) Prod. & $\mathrm{X}$ & & $\mathrm{X}$ & & $\mathrm{X}$ & & & & & & & & & & & & \\
\hline Oryza rufipogon Griff. & $\mathrm{X}$ & & & & $\mathrm{X}$ & $\mathrm{X}$ & & & & & & & & & & & \\
\hline Oserya perpusilla (Went) P.Royen & $\mathrm{X}$ & & & & & & & & & & & & & & & & \\
\hline Paepalanthus fasciculatus (Rottb.) Kunth & & & & $\mathrm{X}$ & & & & & & & & & & & & & \\
\hline Pariana radiciflora Sagot ex Döll & & & & $\mathrm{X}$ & & & & & & & & & & & & & \\
\hline Paspalum multicaule Poir. & & & $\mathrm{X}$ & & & & & $\mathrm{X}$ & & & & & & & & $\mathrm{X}$ & \\
\hline Paspalum pulchellum Kunth & & & $\mathrm{X}$ & & & & & & & & & & & & & & \\
\hline Paspalum repens P.J.Bergius & & & $\mathrm{X}$ & & $\mathrm{X}$ & $\mathrm{X}$ & $\mathrm{X}$ & & & & & & & & $\mathrm{X}$ & & \\
\hline Piriqueta cistoides (L.) Griseb. & & & $\mathrm{X}$ & & $\mathrm{X}$ & & & & & & & & & & & & \\
\hline Pleurostachys sparsiflora Kunth & & & & $\mathrm{X}$ & & & & & & & & & & & & & \\
\hline Prosthechea fragrans (Sw.) W.E.Higgins & & & & $\mathrm{x}$ & & & & & & & & & & & & & \\
\hline Psychotria stipulosa Müll.Arg. & $\mathrm{X}$ & & & & & & & & & & & & & & & & \\
\hline Reimarochloa brasiliensis (Spreng.) Hitchc. & & & $\mathrm{X}$ & & $\mathrm{X}$ & & & & & & & & & & & & \\
\hline Rhynchospora amazonica Poepp. \& Kunth & $\mathrm{X}$ & & & & & & & & & & & & & & & & \\
\hline Rhynchospora divaricata (Ham.) M.T.Strong & $\mathrm{X}$ & & & & & & & & & & & & & & & & \\
\hline Sagittaria guayanensis Kunth & & & $\mathrm{X}$ & & & $\mathrm{X}$ & & & & & & & & & $\mathrm{X}$ & & \\
\hline Saxofridericia aculeata Körn. & & & & $\mathrm{X}$ & & & & & & & & & & & & & \\
\hline Schizaea elegans (Vahl) Sw. & & & & $\mathrm{X}$ & & & & & & & & & & & & & \\
\hline Scleria gaertneri Raddi & $\mathrm{X}$ & & & & $\mathrm{X}$ & & $\mathrm{X}$ & & & & & & & & $\mathrm{X}$ & & \\
\hline Scleria microcarpa Nees ex Kunth & & & $\mathrm{X}$ & & $\mathrm{X}$ & & & & & & & & & & & & \\
\hline Scleria secans (L.) Urb. & $\mathrm{X}$ & & & & $\mathrm{X}$ & & & & & & & & & & & & \\
\hline Sobralia granitica G.A.Romero \& Carnevali & & & & $\mathrm{X}$ & & & & & & & & & & & & & \\
\hline Syngonanthus longipes Gleason & $\mathrm{X}$ & & & & & $\mathrm{X}$ & & & & & & & & & & & \\
\hline Syngonanthus setifolius Hensold & & $\mathrm{X}$ & & & & & & & & & & & & & & & \\
\hline Syngonanthus williamsii (Moldenke) Hensold & & $\mathrm{X}$ & & & & & & & & & & & & & & & \\
\hline Tassadia berteroana (Spreng.) W.D.Stevens & & & $\mathrm{X}$ & & & & $\mathrm{X}$ & & & & & & & & & & \\
\hline Tassadia trailiana (Benth.) Fontella & $\mathrm{X}$ & & $\mathrm{X}$ & & & & & & & & & & & & & & \\
\hline Tillandsia adpressiflora $\mathrm{Mez}$ & & & & $\mathrm{X}$ & & & & & & & & & & & & & \\
\hline Tococa subciliata (DC.) Triana & $\mathrm{X}$ & & & & & & & & & & & & & & & & \\
\hline Trichomanes martiusii C.Presl & $\mathrm{X}$ & $\mathrm{X}$ & & $\mathrm{X}$ & & & & & & & & & & & & & \\
\hline Trichomanes pinnatum Hedw. & & & & $\mathrm{X}$ & & & & & & & & & & & & & \\
\hline Utricularia foliosa L. & $\mathrm{X}$ & & $\mathrm{X}$ & & $\mathrm{X}$ & $\mathrm{X}$ & $\mathrm{X}$ & & & & & & & & $\mathrm{X}$ & & \\
\hline Utricularia gibba L. & $\mathrm{X}$ & & & & $\mathrm{X}$ & $\mathrm{X}$ & & & & & & & & & $\mathrm{X}$ & & \\
\hline Utricularia olivacea C.Wright ex Griseb. & $\mathrm{X}$ & & & & & $\mathrm{X}$ & & & & & & & & & & & \\
\hline Voyria aphylla (Jacq.) Pers. & & & & $\mathrm{X}$ & & & & $\mathrm{X}$ & & & & & & & & & \\
\hline Voyria caerulea Aubl. & & & & $\mathrm{X}$ & & & & & & & & & & & & & \\
\hline Wedelia calycina Rich. & & & $\mathrm{X}$ & & $\mathrm{X}$ & & & & & & & & & & & & \\
\hline Xyris involucrata Nees & & $\mathrm{X}$ & & & & $\mathrm{X}$ & & & & & & & & & & & \\
\hline Xyris subuniflora Malme & & $\mathrm{X}$ & & & & $\mathrm{X}$ & & & & & & & & & & & \\
\hline
\end{tabular}


The floristic similarity $(100 \times J)$ between wetland sites distributed throughout Brazil ranged from 0 to $10.8 \%$ (Tab. 2) indicating low proportion of shared species. The highest $J$-values were obtained between vereda and campo com murundus of the Distrito Federal. In the UPGMA analysis, campinaranas of VNJ and phytophysiognomies of Cerrado (Distrito Federal, Brazil) grouped into one cluster, while others Amazonian ecosystems, Pantanal and Caatinga grouped into the second cluster. The campinarana of USDR appeared separated from these groups (Fig. S1 in supplementary material).

For the 25 species chosen to PDRs at JNP and USDR the data available in digital herbaria (Specieslink and GBIF) showed few previous records of collection in these two sites and surroundings (Figs. 3, 4, 5). Based on the record data, distribution of the species that occurred in the campinaranas of JNP was restricted to the Amazon Basin, while the species of the igapó from this site showed a much wider Neotropical distribution. On the other hand, species from the campinarana and igapó of the USDR showed a wide geographic distribution across the Neotropics (Figs. 3-5).

The sum of 11 axes of the PCA captured $90.4 \%$ of the data variation (Tab. S3 in supplementary material). The number of records varied between 13 and 829 per species and all consensus models were considered good or optimum (Tab. S4 in supplementary material). The algorithm with best values of TSS were ANN and GBM, whilst the SRE showed the worst values. The algorithms used for the consensus model of each species can be consulted in Table S4 in supplementary material.
The PDRs for the Neotropical region were consistent with the patterns shown from data records, just expanding the probability of occurrence around these data records. At the regional level, the SDMs projected contrasting patterns of distribution for igapó and campinarana herbaceous species. The potential distribution range of the USDR igapó species in the Amazon Basin was larger mainly along the major rivers, such as the Amazon and Branco (Fig. 4A), while those from campinarana showed a wide distribution pattern. Two species of the igapó from JNP were widely distributed in the Amazon Basin, while the other three were mostly restricted to the large rivers (Fig. 4B). In contrast, the campinarana species had a wider distributional range in the Northern part of the Amazon Basin (Fig. 3A, B). Miconia subsimplex and Alternanthera paronychioides had a much broader potential distributional range across the Amazon Basin than the area with currently collected occurrences, while the other campinarana species had their potential distribution only narrowly expanded around the current collection areas.

The potential distribution of the selected species in the protected areas was quite variable. Eight of the 10 species at the USDR had a potential distribution of more than $60 \%$, while the other two species had a limited occurrence around $20 \%$ for the reserve (Figs. 3A and 4A). On the other hand, the species that occurred at JNP had a high potential distribution in small areas within the protected area (Fig. 4B). For the species that occurred in more than one ecosystem and/or study site, the potential distributional range in the reserves was over $40 \%$ and quite variable (Fig. 5). The consensus models predicted well the occurrence of $88 \%$ (22 out of 25) of the species in the inventoried protected areas.

Table 2. Jaccard Similarity Index $\left(\mathrm{J}^{*} 100\right)$ between the wetlands (campinarana and igapó) inventoried in Parque Nacional do Jaú (JC= Jaú campinarana, JI= Jaú igapó) and Reserva de Desenvolvimento Sustentável Uatumã (UC= Uatumã campinarana, UI= Uatumã igapó) and other Brazilian wetland inventories: 1) Amazonian várzea floodplains (Junk \& Piedade 1993); 2) campinaranas of Parque Nacional do Viruá (Costa et al. 2016); 3) clear-water igapó of Tapajos River (Crema 2017); 4) wetlands in the savanna biome, gallery forests (4A), campo limpo úmido (4B), campo úmido (4C), campo sujo com murundus (4D), campo limpo de murundus (4E), campo com murundus (4F) and vereda (4G) (Chacon et al. 2015); 5) Pantanal (Pott \& Pott 1997); 6) wetlands in the savanna biome (Cerrado), vereda (Silva et al. 2018); 7) semi-arid Caatinga (Torres et al. 2016).

\begin{tabular}{|c|c|c|c|c|c|c|c|c|c|c|c|c|c|c|c|c|c|}
\hline & JI & JC & UI & UC & 1 & 2 & 3 & $4 A$ & $4 B$ & $4 C$ & 4D & $4 E$ & $4 F$ & 46 & 5 & 6 & 7 \\
\hline JI & & 10.26 & 6.90 & 1.61 & 3.20 & 3.20 & 8.11 & 0.37 & 0.00 & 0.00 & 0.00 & 0.00 & 0.00 & 0.00 & 2.92 & 0.00 & 0.65 \\
\hline JC & 10.26 & & 0.00 & 2.56 & 0.00 & 1.50 & 0.00 & 0.00 & 0.00 & 0.00 & 0.00 & 0.00 & 0.00 & 0.00 & 0.00 & 0.00 & 0.00 \\
\hline UI & 6.90 & 0.00 & & 0.00 & 7.12 & 3.74 & 7.04 & 0.18 & 0.00 & 0.74 & 2.27 & 0.00 & 0.00 & 1.08 & 2.53 & 1.32 & 3.45 \\
\hline UC & 1.61 & 2.56 & 0.00 & & 0.00 & 0.90 & 0.00 & 0.18 & 0.00 & 0.00 & 0.00 & 0.00 & 0.00 & 0.00 & 0.00 & 0.43 & 0.00 \\
\hline 1 & 3.20 & 0.00 & 7.12 & 0.00 & & 3.69 & 5.92 & 0.65 & 0.00 & 0.55 & 0.00 & 0.34 & 0.32 & 0.31 & 10.82 & 1.10 & 9.57 \\
\hline 2 & 3.20 & 1.50 & 3.74 & 0.90 & 3.69 & & 9.09 & 0.85 & 0.43 & 2.03 & 0.48 & 0.87 & 1.61 & 4.88 & 7.67 & 10.06 & 2.28 \\
\hline 3 & 8.11 & 0.00 & 7.04 & 0.00 & 5.92 & 9.09 & & 0.36 & 0.00 & 0.65 & 0.00 & 0.00 & 0.00 & 0.90 & 12.02 & 0.81 & 3.07 \\
\hline $\mathbf{4 A}$ & 0.37 & 0.00 & 0.18 & 0.18 & 0.65 & 0.85 & 0.36 & & 2.57 & 3.65 & 0.76 & 1.65 & 1.59 & 4.31 & 0.69 & 3.17 & 0.31 \\
\hline 4B & 0.00 & 0.00 & 0.00 & 0.00 & 0.00 & 0.43 & 0.00 & 2.57 & & 1.35 & 3.57 & 5.13 & 5.21 & 5.94 & 0.00 & 4.29 & 0.00 \\
\hline 4C & 0.00 & 0.00 & 0.74 & 0.00 & 0.55 & 2.03 & 0.65 & 3.65 & 1.35 & & 2.48 & 4.96 & 8.44 & 12.34 & 0.00 & 5.82 & 0.00 \\
\hline 4D & 0.00 & 0.00 & 2.27 & 0.00 & 0.00 & 0.48 & 0.00 & 0.76 & 3.57 & 2.48 & & 0.00 & 1.35 & 3.85 & 0.00 & 1.40 & 0.00 \\
\hline $4 E$ & 0.00 & 0.00 & 0.00 & 0.00 & 0.34 & 0.87 & 0.00 & 1.65 & 5.13 & 4.96 & 0.00 & & 2.06 & 3.96 & 0.40 & 2.55 & 0.00 \\
\hline 4F & 0.00 & 0.00 & 0.00 & 0.00 & 0.32 & 1.61 & 0.00 & 1.59 & 5.21 & 8.44 & 1.35 & 2.06 & & 10.71 & 0.00 & 5.69 & 0.56 \\
\hline 4G & 0.00 & 0.00 & 1.08 & 0.00 & 0.31 & 4.88 & 0.90 & 4.31 & 5.94 & 12.34 & 3.85 & 3.96 & 10.71 & & 1.09 & 8.13 & 0.00 \\
\hline 5 & 2.92 & 0.00 & 2.53 & 0.00 & 10.82 & 7.67 & 12.02 & 0.69 & 0.00 & 0.00 & 0.00 & 0.40 & 0.00 & 1.09 & & 1.47 & 4.69 \\
\hline 6 & 0.00 & 0.00 & 1.32 & 0.43 & 1.10 & 10.06 & 0.81 & 3.17 & 4.29 & 5.82 & 1.40 & 2.55 & 5.69 & 8.13 & 1.47 & & 0.63 \\
\hline 7 & 0.65 & 0.00 & 3.45 & 0.00 & 9.57 & 2.28 & 3.07 & 0.31 & 0.00 & 0.00 & 0.00 & 0.00 & 0.56 & 0.00 & 4.69 & 63 & \\
\hline
\end{tabular}




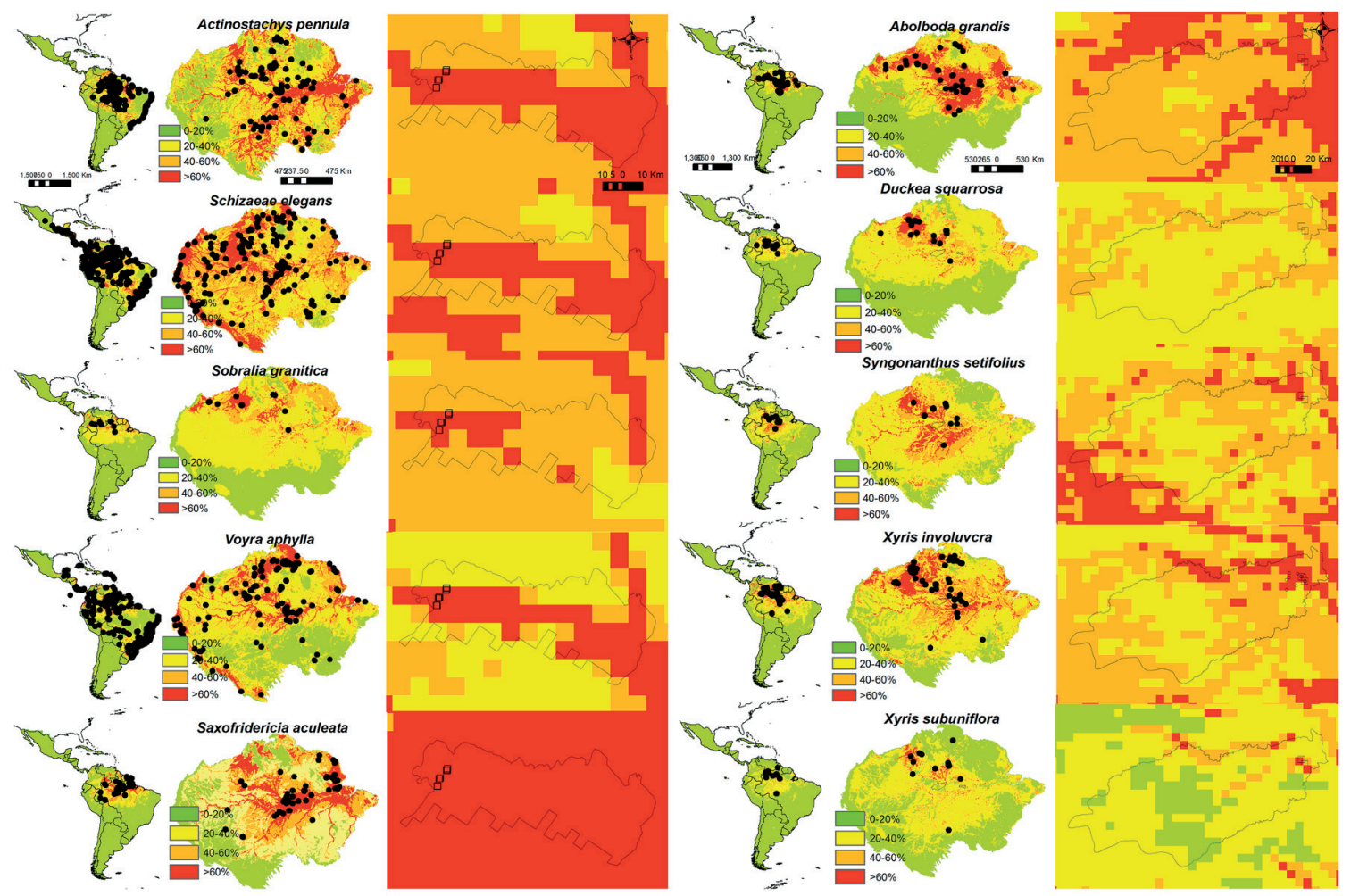

Figure 3. Current (black dots) and potential (colored area) distribution of the most frequent herbaceous plants of the campinarana ecosystem in A) the Reserva de Desenvolvimento Sustentável Uatumã (indicated by the shape in the high-resolution maps). B) the Parque Nacional do Jaú (indicated by the shape in the high-resolution maps).
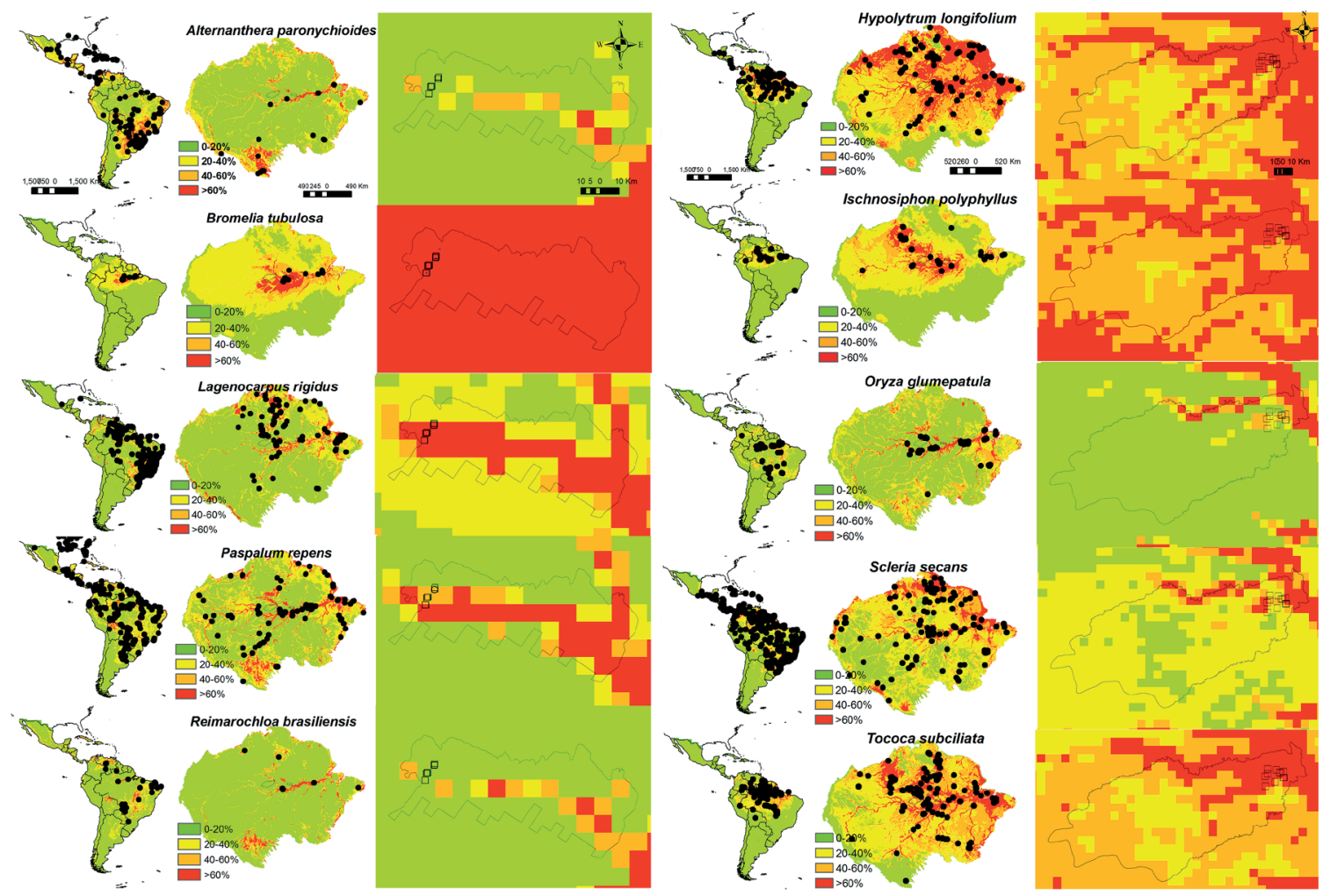

Figure 4. Current (black dots) and potential (colored area) distribution of the most frequent herbaceous plants of the igapó ecosystem in: A) the Reserva de Desenvolvimento Sustentável Uatumã (indicated by the shape in the high-resolution maps); B) the Parque Nacional do Jaú (indicated by the shape in the high-resolution maps). 

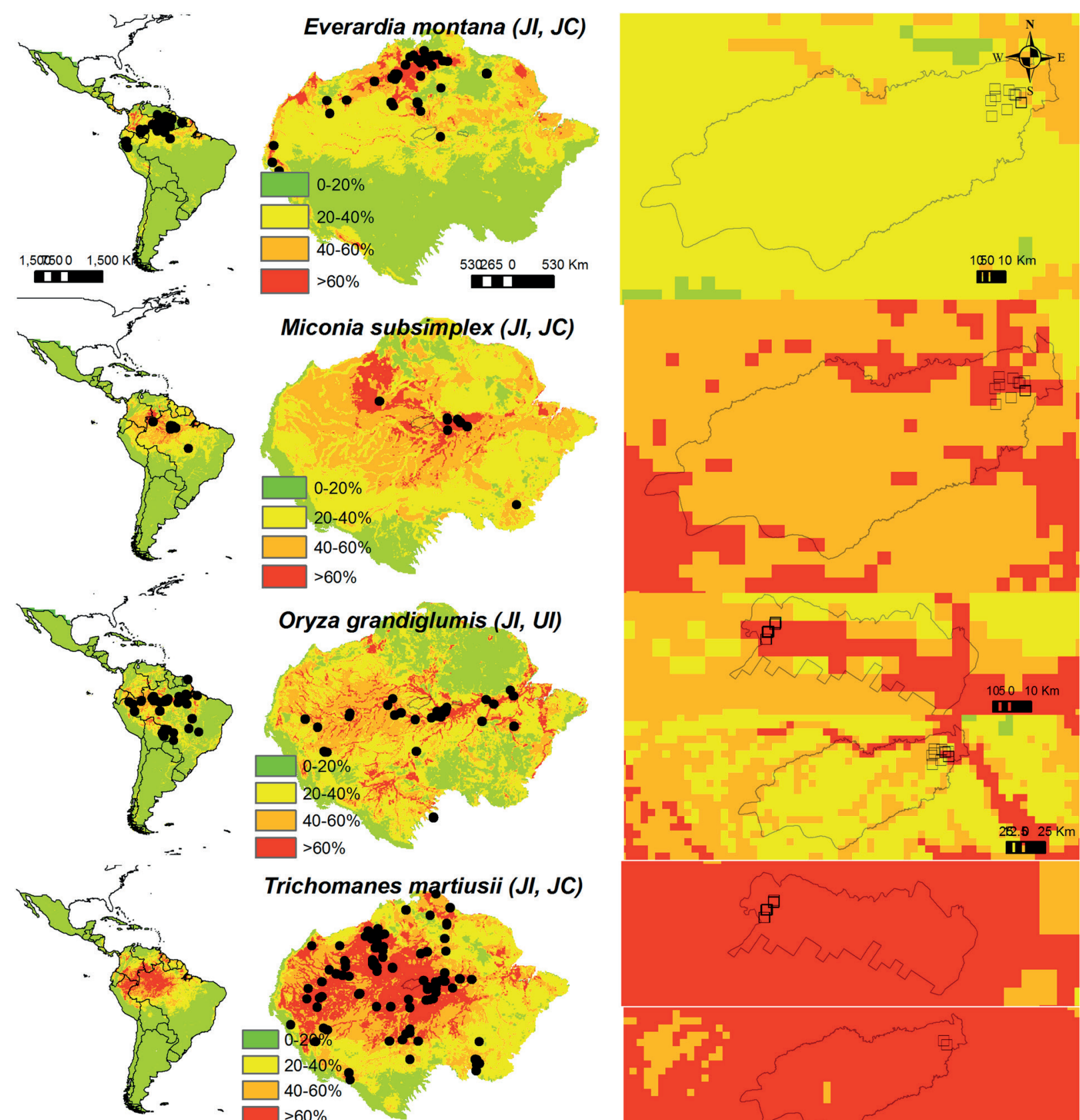

Trichomanes martiusii (JI, JC)
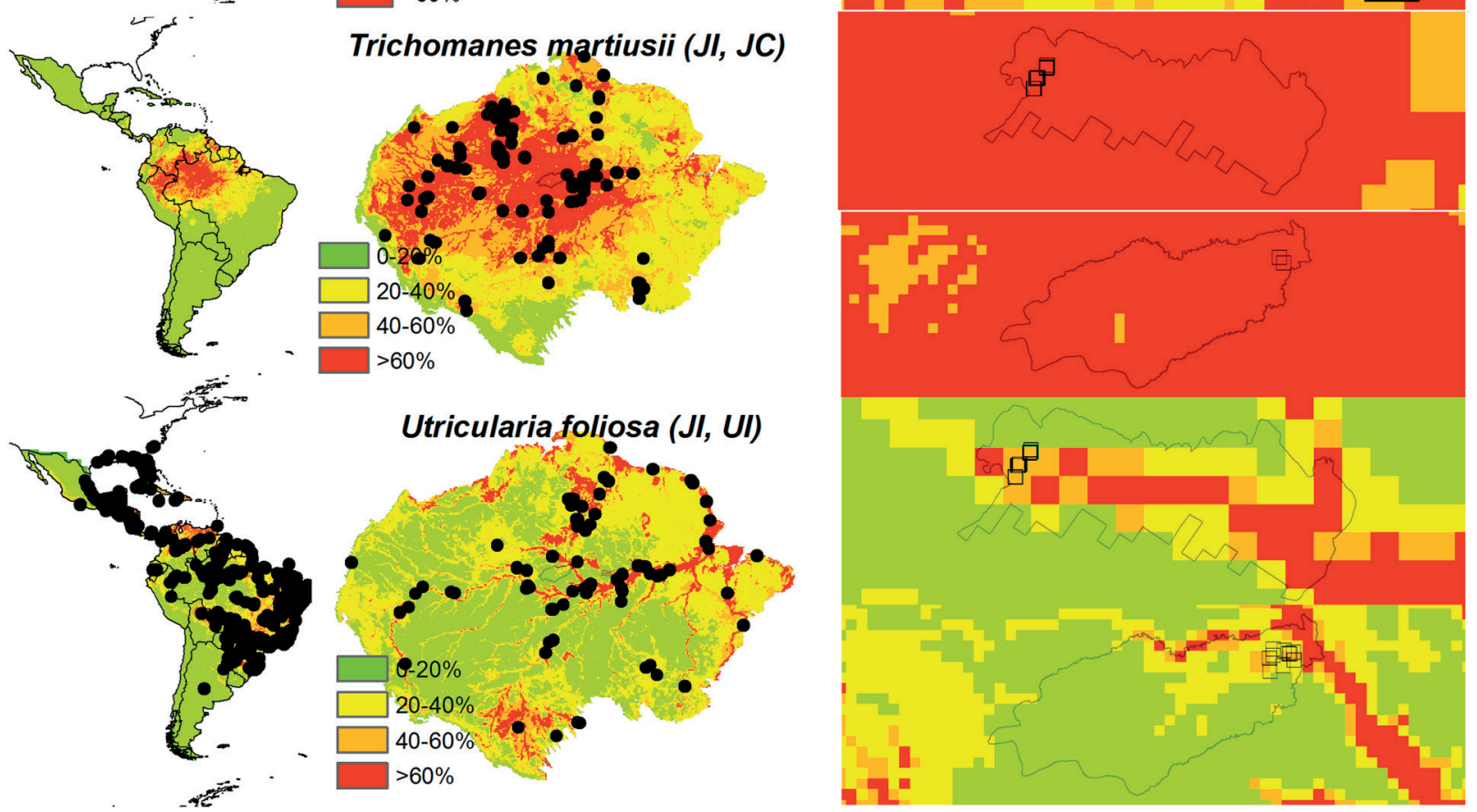

Figure 5. Current (black dots) and potential (colored area) distribution of the most frequent herbaceous that occurred in more than one sample in the campinarana and igapó wetlands of the JNP and USDR (shapes indicated in the high-resolution maps); JC= Jaú campinarana, JI= Jaú igapó, UI= Uatumã igapó. 


\section{Discussion}

The comparison of our species list with those of other Brazilian wetlands revealed a very low floristic similarity. With 29 species, Amazonian várzea (Junk \& Piedade 1993) presented the highest number of species in common with our inventories, being most similar to the igapó floodplains of both study sites. This might be related to mutual adaptation of species to monomodal flood pulses of high amplitudes. Campinaranas of the VNP (Costa et al. 2016) had 18 species in shared with the PELD-MAUA campinarana sites, showing a higher similarity with the same ecosystem at both sites. In general, the várzea floodplain of Central Amazonia has a higher richness and diversity of herbaceous aquatic plants compared to the igapó (Lopes et al. 2014; 2019) and campinaranas (Costa et al. 2016). Both the igapós and campinaranas have other stressors such as low nutritional quality of soils and anoxic or hypoxic conditions induced by flooding or waterlogging (Anderson 1981; Wittmann et al. 2010; Junk et al. 2015; Targhetta et al. 2015), likely contributing to the low observed species richness. Although many species of the campinaranas are not resistant to prolonged flooding (Targhetta et al. 2015), the oligotrophic conditions make aquatic herbaceous species richness of igapó and campinarana comparable to those of other extreme environments, such as those found in arid and semiarid ecosystems of the dry forest (Caatinga) of Northeastern Brazil (Henry-Silva et al. 2010).

In the upper Negro river basin, several studies indicated high floristic similarity between the arboreal flora of the igapós and campinaranas (Kubitzki 1989; Daly \& Prance 1989; Damasco et al. 2013). This similarity may be linked to the fact that the vegetation upon nutrient-poor soils is strongly floristically related (Guillaumet 1987; Tuomisto et al. 1995). This is not what we found. Despite occurring in extremely nutrient-poor and acidic soils (Adeney et al. 2016), the studied igapós and campinaranas showed an extremely low floristic similarity of herbaceous plants even at the family level. Similar results were described by Targhetta et al. (2015) for the arboreal vegetation, which observed an extremely low floristic similarity between the campinarana and igapó forests in the USDR. Sand content and other physiochemical soil properties might vary at macro- and microscales and likely have a strong effect on vegetation structure of white-sand ecosystems (Demarchi et al. 2018). Because of the geographic isolation in a terra-firme matrix, campinaranas hardly recover species that have once lost (Álvarez-Alonso et al. 2013).

The performance of the eight tested models varied, however results in terms of ROC sensitivity were similar, except for the SRE and GBM, which performed lower than the other tested algorithms. The Maxent is often reported as performing well with low sample sizes (Pearson 2007; Wisz et al. 2013). Besides Maxent, ANN, FDA and RF also provided good accuracy for all species with small numbers of samples (9-24). As a result, reliability of the consensus models was rated "good" and "optimum" by ROC sensitivity for all species. So far there is no single PDR model that perform well in all cases (Araújo \& New 2007; Li \& Wang 2013) and the use of consensus models encompassing different kinds of algorithms has been proved to be a successful strategy (Araújo \& New, 2007; Loyola et al. 2012; Ochoa-Ochoa et al. 2016). This was also the case here, where the use of multi algorithms models were efficient in predicting the occurrence of aquatic herbaceous plants in the Neotropics and at regional (Amazon basin) level. On a more local scale, we were able to predict the distribution of 22 out of the 25 species when data point locations collected for each of these species in JNP and USDR were overlaid on the generated PDR maps.

The more restricted PDR of campinarana species compared to igapó species corroborates findings from other studies that investigated the distribution of different campinarana taxa. Amazonian white-sand areas are known for their elevated degree of both endemic tree (Fine et al. 2004; Guevara et al. 2016) and birds' species (Borges et al. 2001; Guilherme \& Borges 2011). In the central Amazon, campinaranas are fragmented, small-sized, and insulated areas that are interspersed in dense Amazon rainforest (Adeney et al. 2016). In campinaranas, small variations in soil grain size and nutrient contents can influence species composition and distribution at local scales (Damasco et al. 2013; Demarchi et al. 2018); soils consist of almost pure quartz sands and concentration of important nutrients in the topsoil, such as $\mathrm{K}, \mathrm{Ca}$ and $\mathrm{Mg}$, is even lower than in igapó substrates (Targhetta et al. 2015). Due to the low water retention capacity of sandy soils, campinarana plant species undergo severe drought stress during the dry seasons (Junk et al. 2011), while soils turn into hydromorphic or even superficially inundated during the rainy seasons.

For campinarana trees species richness and forest stature, the water-saturation gradient is an important determinant, with the lowest richness and lowest stature occurring in areas of the longest saturation (Junk et al. 1989; Worbes 1997; Wittmann \& Junk 2016). As arboreal competition is low and areas are relatively unshaded upon these waterlogged soils, they are the habitat where herbaceous species are most competitive (Junk et al. 2011). These areas, however, are mostly small and isolated and have reduced connectivity to other wetlands. Propagules from herbaceous species as such originate from the surrounding terra-firme forest, where their occurrence is rare or in very low population density or, more likely, have to be brought in by animals from distant areas (Macedo \& Prance 1978). Like trees in the surrounding campinarana forest, it is thus most likely that most herbaceous species developed high degrees of endemism under these conditions, which is expressed in their narrow PDR within the Amazon basin. 
Conversely, herbaceous species of igapós are widely distributed over the Neotropical region. River floodplains in the Amazon cover an area of more than $750,000 \mathrm{~km}^{2}$ (Wittmann \& Junk 2016). Although white-water and black-water river floodplains are known for their diverging flora for both, arboreal and herb communities (i.e., Junk et al. 2012; 2015), most trees and herbaceous species from one ecosystem are known to occur with low population densities in the other. The river floodplains thus form highly connected corridors for plant dispersal, which is promoted through water currents, fish and/or other aquatic animals (Parolin et al. 2013; Geremew \& Triest 2019). Some Amazonian rivers also originate from outside the Amazon basin, such as the Xingu and Tocantins rivers, come from the southern Brazilian Shield and Cerrado biome. For trees, rivers are important migration corridors that connect the Amazon, Orinoco, Cerrado and Atlantic rainforest domains (Wittmann et al. 2017). Herbaceous floodplain species often have very effective dispersal mechanisms through hydrochory and/or vegetative propagation (Piedade et al. 2019), and it is therefore not surprising that most of them had wide PDR across the entire Neotropical region.

The narrow PDR of many campinarana herbs provides one more argument for the urgent need of more inventories and the establishment of efficient conservation strategies in the unique Amazonian white-sand ecosystems. Some of the studied species are listed in the IUCN Red List (IUCN 2020) with DD, because do not have enough data to be even categorized. An urgent increase in areas of floristic inventories and sampling effort is necessary to generate information that subsidizes the risk assessment of many species, since several of them may be threatened due to anthropogenic disturbance in this vulnerable environment (Ferreira et al. 2013; Adeney et al. 2016).

\section{Conclusion}

The environmental variables were able to calculate the potential distribution with adequate ROC sensitivity percentage, efficiently predicting the occurrence of all analyzed species at the PELD-MAUA sites. The herbaceous species found in the igapó are widely distributed in the Neotropics, indicating an absence of barriers for their dispersal. Most campinarana species had their potential distribution more restricted to the Amazon Basin, probably due to the distribution of these ecosystems in isolated patches in the Amazonia rainforest matrix. There was a low floristic similarity of less than $11 \%$ between the campinarana and igapós areas of the two PELD-MAUA sites, indicating that local environmental factors linked to hydrology, soils and disturbance events need to be better investigated to understand these local characteristics and to establish adequate management plans at local and regional levels.

\section{Acknowledgements}

Long-term Ecological Research Network-PELD (CNPq/CAPES/FAPS/BC,NEWTON PROGRAM FUND 441590/2016-0 and MCTI/CNPq/FAPs 403792/20126); INPA/MAUA Group, PPI:1090-5; CAPES (Finance Code 001); FAPEAM (017/2014); INCT-ADAPTA (CNPq: 465540/2014-7; FAPEAM: 062.1187/2017). A.C. Franco and M.T.F. Piedade are recipients of CNPq productivity fellowships (311362/2019-2 and 310547/2016-4). Secretaria de Estado do Meio Ambiente (SEMA) and Amazon Tall Tower Observatory (ATTO) for support in USDR and ICMBIO for support in JNP. We are grateful to the parataxonomist José F. Ramos for his help in identifying the specimens.

\section{References}

Adeney J, Christensen N, Vicentini A, Cohn-Haft M. 2016. White-sand Ecosystems in Amazonia. Biotropica 48: 7-23.

Allouche O, Tsoar A, Kadmon R. 2006. Assessing the accuracy of species distribution models: prevalence, kappa and the true skill statistic (TSS). Journal of Applied Ecology 43: 1223-1232.

Álvarez-Alonso J, Metz MR, Fine PVA. 2013. Habitat specialization by birds in Western Amazonian white-sand forests. Biotropica 45: 365- 372.

Anderson AB. 1981. White sand vegetation of Brazilian Amazonia. Biotropica 13: 199-210.

APG - Angiosperm Phylogeny Group III. 2009. An update of the Angiosperm Phylogeny Group classification for the orders and families of flowering plants: APG III. Botanical Journal of the Linnean Society 161: 105-121.

Araújo MB, New M. 2007. Ensemble forecasting of species distributions. Trends in Ecology \& Evolution 22: 42-47.

Assahira C, Piedade MTF, Trumbore SE, et al. 2017. Tree mortality of a flood-adapted species in response of hydrographic changes caused by an Amazonian river dam. Forest Ecology and Management 396: 113-123.

Atuesta-Ibargüen DJ. 2019. Composición florística y formas de vida de las macrófitas acuáticas de la serranía de La Lindosa (Guaviare), Guayana colombiana. Caldasia 41: 301-312.

Barbet-Massin M, Jiguet F, Albert CH, Thuiller W. 2012. Selecting pseudoabsences for species distribution models: how, where and how many? Methods in Ecology and Evolution 3: 327-338.

Borges SH, Cohn-Haft M, Carvalhaes AMP, Henriques LM, Pacheco JF, Whittaker A. 2001. Birds of Jaú National Park, Brazilian Amazon: Species checklist, biogeography, and conservation. Ornitologia Neotropical 12: 109-140.

Breiman L, Friedman JH, Olshen RA, Stone CJ. 1984. Classification and Regression Trees. The Wadsworth Statistics Probability Series. New York, Chapman \& Hall/CRC.

Breiman L. 1999. Random forest. Machine Learning 45: 1-35.

Brown JL, Yoder AD. 2015. Shifting ranges and conservation challenges for lemurs in the face of climate change. Ecology and Evolution 5: 1131-1142.

Chacon RG, Souza-Oliveira M, Paiva VF, Hermeto TVG, Silva MC. 2015. Flora da Estação Ecológica do Jardim Botânico de Brasília, Distrito Federal. Heringeriana 8: 131-201.

Chambers PA, Lacoul P, Murphy KJ, Thomaz SM. 2008. Global diversity of aquatic macrophytes in freshwater. Hydrobiologia 595: 9-26.

Coomes DA. 1997. Nutrient status of Amazonian Caatinga forests in a seasonally dry area: nutrient fluxes in litterfall and analyses of soils. Canadian Journal of Forest Research 27: 831-839.

Costa SM, Barbosa TDM, Bittrich V, Amaral MDCE. 2016. Floristic survey of herbaceous and subshrubby aquatic and palustrine angiosperms of Viruá National Park, Roraima, Brazil. PhytoKeys 58: 21-48. 
Crema LC. 2017. Caracterização de igapós de águas claras e pretas e suas disponibilidades alimentares para o peixe-boi-da-Amazônia (Trichechus inunguis). PhD Thesis. Instituto Nacional de Pesquisas da Amazônia, Manaus.

CRIA - Centro de Referência em Informação Ambiental. 2020. Species links. http://splink.cria.org.br/centralized_search?criaLANG=pt. 10 Mar. 2020.

Daly DC, Prance GT. 1989. Brazilian Amazon. In: Campbell DG, Hammond HD. (eds.) Floristic inventory of tropical countries. Bronx, New York Botanical Garden. p. 401-426.

Daly DC, Silveira M, Medeiros H, Castro W, Obermüller FA. 2016. The white-sand vegetation of Acre, Brazil. Biotropica 48: 81-89.

Damasco G, Vicentini A, Castilho CV, Pimentel TP, Nascimento HEM. 2013. Disentangling the role of edaphic variability, flooding regime, and topography of Amazonian white-sand vegetation. Journal of Vegetation Science 24: 384-394.

Demarchi LO, Scudeller VV, Moura LC, et al. 2018. Floristic composition, structure and soil-vegetation relations in three white-sand soil patches in central Amazonia. Acta Amazonica 48: 46-56.

Dormann CF, Elith J, Bacher S, et al. 2013. Collinearity: A review of methods to deal with it and a simulation study evaluating their performance. Ecography 36: 27-46.

Esri. 2013. Arcgis explorer website. http://www.esri.com/software/arcgis/ explorer/index.html . 03 Mar. 2013.

Ferreira LV, Chaves PP, Cunha DDA, Rosário AS, Parolin P. 2013. A extração ilegal de areia como causa do desaparecimento de campinas e campinaranas no estado do Pará, brasil. Pesquisas, Botânica 64: 157-173.

Ferreira LV. 2000. Effects of flooding duration on species richness, floristic composition and forest structure in river margin habitat in Amazonian blackwater floodplain forests: implications for future design of protected areas. Biodiversity and Conservation 9: 1-14.

Fine PVA, Mesones I, Coley PD. 2004. Herbivores promote habitat specialization by trees in Amazonian forests. Science 305: 663-665.

Forzza RC, Leitman PM, Costa AF, et al. 2020. Brazilian Species List. Retrieved from: http://floradobrasil.jbrj.gov.br/2020.09 Feb. 2020.

Franco W, Dezzeo N. 1994. Soils and soil-water regime in the terrafirme-caatinga forest complex near San Carlos de Rio Negro, state of Amazonas, Venezuela. Interciencia 19: 305-316.

Friedman J, Hastie T, Tibshirani R. 2000. Additive logistic regression: a statistical view of boosting (with discussion and a rejoinder by the authors). The Annals of Statistics 28: 337-407.

GBIF development team. 2020 GBIF: The Global Biodiversity Information Facility. Retrieved from: https://www.gbif.org/what-is-gbif $10 \mathrm{Jan}$ 2020.

Geremew A, Triest L. 2019. Hydrological connectivity and vegetative dispersal shape clonal and genetic structure of the emergent macrophyte Cyperus papyrus in a tropical highland lake (Lake Tana, Ethiopia). Hydrobiologia 843: 13-30.

Giannini TC, Siqueira MF, Acosta AL, Barreto FC, Saraiva AM, Alves-dosSantos I. 2012. Desafios atuais da modelagem preditiva de distribuição de espécies. Rodriguésia 63: 733-749.

Gomes VH, Mayle FE, Gosling WD, Vieira IC, Salomão RP, Steege H. 2020. Modelling the distribution of Amazonian tree species in response to long-term climate change during the Mid-Late Holocene. Journal of Biogeography 47: 1530-1540.

Guevara JE, Damasco G, Baraloto C, et al. 2016. Low phylogenetic beta diversity and geographic neo-endemism in Amazonian white-sand forests. Biotropica 48: 34-46.

Guilherme E, Borges SH. 2011. Ornithological records from a Campina/ Campinarana enclave on the upper Juruá River, Acre, Brazil. The Wilson Journal of Ornithology 123: 24-32.

Guillaumet JL. 1987. Some structural and floristic aspect of the forest. Experientia 43: 241-251.

Guisan A, Zimmermann NE. 2000. Predictive habitat distribution models in ecology. Ecological Modelling 135: 147-186.

Hastie T, Tibshirani R, Buja A. 1994. Flexible discriminant analysis by optimal scoring. Journal of the American Statistical Association 89: 1255-1270.
Henry-Silva GG, Moura RSTD, Dantas LLDO. 2010. Richness and distribution of aquatic macrophytes in Brazilian semi-arid aquatic ecosystems. Acta Limnologica Brasiliensia 22: 147-156.

Hopfield JJ. 1982. Neural networks and physical systems with emergent collective computational abilities. Proceedings of the National Academy of Sciences 79: 2554-2558.

IDESAM. 2009. Plano de Gestão da Reserva de Desenvolvimento Sustentável do Uatumã. Versão para consulta pública. Manaus, Instituto de Conservação e Desenvolvimento Sustentável do Amazonas. https://idesam.org/publicacao/plano-pesca-esportiva-rdsu.pdf.

IUCN - International Union for Conservation of Nature. 2020. The IUCN Red List of Threatened Species. Version 2020-2. https://www. iucnredlist.org. 09 Feb. 2020.

Jiguet F, Barbet-Massin M, Chevallier D. 2011. Predictive distribution modelsapplied to satellite tracks: modelling the western African winter range of Euro-pean migrant Black Storks Ciconia nigra. Journal of Ornithology 152: 111-118.

Junk WJ, Bayley PB, Sparks RE. 1989. The flood pulse concept in riverfloodplain systems. Canadian Special Publications for Fisheries and Aquatic Sciences 106: 110-127.

Junk WJ, Piedade MTF, Lourival R, et al. 2014. Brazilian wetlands: their definition, delineation, and classification for research, sustainable management, and protection. Aquatic Conservation: Marine and Freshwater Ecosystems 24: 5-22.

Junk WJ, Piedade MTF, Schöngart J, Cohn-Haft M, Adeney JM, Wittmann F. 2011. A classification of major naturally-occurring Amazonian lowland wetlands. Wetlands 31: 623-640.

Junk WJ, Piedade MTF, Schöngart J, Wittmann F. 2012. A classification of major natural habitats of Amazonian white-water river floodplains (várzeas). Wetlands Ecology and Management 20: 461-475.

Junk WJ, Piedade MTF. 1993. Herbaceous plants of the Amazon floodplain near Manaus: Species diversity and adaptations to the flood pulse. Amazoniana 12: 467-484.

Junk WJ, Piedade MTF. 1994. Species diversity and distribution of herbaceous plants in the floodplain of the middle Amazon. Internationale Vereinigung für Theoretische und Angewandte Limnologie Verhandlungen 25: 1862-1865.

Junk WJ, Wittmann F, Schöngart J, Piedade MTF. 2015. A classification of the major habitats of Amazonian black-water river floodplains and a comparison with their white-water counterparts. Wetlands Ecology and Management 23: 677-693.

Kubitzki K. 1989. The ecogeographical differentiation of Amazonian inundation forests. Plant Systematics and Evolution 162: 285-304.

Lacoul P, Freedman B. 2006. Environmental influences on aquatic plants in freshwater ecosystems. Environmental Reviews 14: 89-136.

Leutner B, Horning N, Leutner MB. 2017. Package 'RStoolbox'. R Foundation for Statistical Computing, Version 0.1. https://cran.rproject.org/web/packages/RStoolbox/RStoolbox.pdf.

Li X, Wang Y. 2013. Applying various algorithms for species distribution modelling. Integrative Zoology 8: 124-135.

Lobo G, Wittmann F, Piedade MTF. 2019. Response of black-water floodplain (igapó) forests to flood pulse regulation in a dammed Amazonian river. Forest Ecology and Management 434: 110-118.

Lopes A, Crema LC, Demarchi LO, et al. 2019. Herbáceas Aquáticas em Igapós de Água Preta Dentro e Fora de Unidades de Conservação no Estado do Amazonas. Biodiversidade Brasileira 9: 1-11.

Lopes A, Wittmann F, Schöngart J, Householder JE, Piedade MTF. 2017. Modeling of regional-and local-scale distribution of the genus Montrichardia Crueg. (Araceae). Hydrobiologia 789: 45-57.

Lopes A, Wittmann F, Schöngart J, Piedade MTF. 2014. Herbáceas aquáticas em seis igapós na Amazônia Central: composição e diversidade de gêneros. Revista Geográfica Acadêmica 8: 5-17.

Loyola RD, Lemes P, Nabout JC, et al. 2012. A straightforward conceptual approach for evaluating spatial conservation priorities under climate change. Biodiversity and Conservation 22: 483-495.

Macedo M, Prance GT. 1978. Notes on the vegetation of Amazonia II. The dispersal of plants in Amazonian white sand campinas: The campinas as functional islands. Brittonia 30: 203-215. 


\section{Aline Lopes, Layon Oreste Demarchi, Augusto Cesar Franco, et al.}

Marchioretto MS, Windisch PG, de Siqueira JC. 2004. Padrões de distribuição geográfica das espécies de Froelichia Moench e Froelichiella RE Fries (Amaranthaceae) no Brasil. Iheringia, Série Botânica 59: 149-160.

McCullagh P, Nelder JA. 1989. Generalized Linear Models. London, Chapman \& Hall / CRC Monographs on Statistics \& Applied Probability.

Melack JM, Hess LL. 2010. Remote sensing of the distribution and extent of wetlands in the Amazon basin. In: Junk WJ, Piedade MTF, Wittmann F, Schöngart J, Parolin P. (eds.) Amazonian floodplain forests: Ecophysiology, biodiversity, and sustainable management. New York, Springer. p. 43-59.

Murphy K, Efremov A, Davidson TA, et al. 2019. World distribution, diversity and endemism of aquatic macrophytes. Aquatic Botany 158: 103-127.

Ochoa-Ochoa LM, Flores-Villela OA, Bezaury-Creel JE. 2016. Using one vs. many, sensitivity and uncertainty analyses of species distribution models with focus on conservation area networks. Ecological Modelling 320: 372-382.

Parolin P, Wittmann F, Ferreira LV. 2013. Fruit and seed dispersal in Amazonian floodplain trees-a review. Ecotropica 19: 15-32.

Pearson RG. 2007. Species' distribution modeling for conservation educators and practitioners. Lessons in Conservation 3: 54-89.

Pecchi M, Marchi M, Burton V, et al. 2019. Species distribution modelling to support forest management. A literature reviews. Ecological Modelling 411: 108817 doi: 10.1016/j.ecolmodel.2019.108817

Phillips SJ, Anderson RP, Schapire RE. 2006. Maximum entropy modeling of species geographic distributions. Ecological Modelling 190: 231-259.

Piedade MTF, Junk WJ, D’Angelo SA, Wittmann F, Schöngart J, Lopes A. 2010. Aquatic herbaceous plants of the Amazon floodplains: state of the art and research needed. Acta Limnologica Brasiliensia 2: 165-17.

Piedade MTF, Lopes A, Demarchi LO, et al. 2019. Guia de Campo de Herbáceas Aquáticas: várzea amazônica. 1st. edn. Manaus, Editora INPA.

Pott VJ, Pott A. 1997. Checklist das macrófitas aquáticas do Pantanal, Brasil. Acta Botanica Brasilica 11: 215-227.

Prance GT. 1996. Islands in Amazonia. Philosophical Transactions of the Royal Society of London. Series B: Biological Sciences 351: 823-833.

R Development Core Team 2020. R: A language and environment for statistical computing. R Foundation for Statistical Computing, Vienna, Austria. https://www.R-project.org/.09 Feb. 2020.

Rocha M, Assis RL, Piedade MTF, et al. 2019. Thirty years after Balbina Dam: diversity and floristic composition of the downstream floodplain forest, Central Amazon, Brazil. Ecohydrology 12: e2144. doi: 10.1002/eco.2144

Santana Jr. PA, Kumar L, Silva RS, Pereira JL, Picanço MC. 2019. Assessing the impact of climate change on the worldwide distribution of Dalbulus maidis (DeLong) using MaxEnt. Pest Management Science 75: 2706-2715.
Silva DPD, Amaral AG, Bijos NR, Munhoz CBR. 2018. Is the herb-shrub composition of veredas (Brazilian palm swamps) distinguishable? Acta Botanica Brasilica 32: 47-54.

Targhetta N, Kesselmeier J, Wittmann F. 2015. Effects of the hydroedaphic gradient on tree species composition and aboveground wood biomass of oligotrophic forest ecosystems in the central Amazon basin. Folia Geobotanica 50: 185- 205.

Thuiller W, Georges D, Engler R, Breiner F. 2019. biomod2: Ensemble platform for species distribution modeling. R package version 3.3-7.1. https://CRAN.Rproject.org/package=biomod2.09 Set. 2019.

Torres CRM, Fernando EM, Lucena MF. 2016. Checklist de plantas aquáticas em trechos de caatinga do semiárido paraibano, Nordeste do Brasil. Gaia Scientia 10: 284-296.

Tuomisto H, Ruokolainen K, Kalliola R, Linna A, Danjoy W, Rodriguez Z. 1995. Dissecting Amazonian biodiversity. Science 269: 63-66.

Wisz MS, Pottier J, Kissling WD, et al. 2013. The role of biotic interactions in shaping distributions and realised assem-blages of species: implications for species distribution modelling. Biological Reviews 88: 15-30.

Wittmann F, Householder E, Piedade MTF, et al. 2012. Habitat specificity, endemism and the Neotropical distribution of Amazonian white-water floodplain trees. Ecography 36: 690-707.

Wittmann F, Junk WJ. 2016. The Amazon river basin. In: Finlayson CM, Milton GR, Prentice RC, Davidson NC. (eds.) The Wetland book II: distribution,description and conservation. Heidelberg, Berlin, New York, Springer-Verlag. p. 1-16.

Wittmann F, Marques MCM, Damasceno Júnior C, et al. 2017. The Brazilian freshwater wetscape: Changes in tree community diversity and composition on climatic and geographic gradients. PLOS ONE 12: e0175003. doi: 10.1371/journal.pone.0175003

Wittmann F, Schöngart J, Junk WJ. 2010. Phytogeography, Species Diversity, Community Structure and Dynamics of Central Amazonian Floodplain Forests. In: Junk WJ, Piedade MTF, Wittmann F, Schöngart J, Parolin P. (eds.) Amazonian Floodplain Forests: Ecophysiology, Biodiversity and Sustainable Management. Dordrencht, Heidelbergh, London, New York, Ecological Studies, Springer. p. 61-102.

Worbes M. 1997. The Forest Ecosystem of the Floodplains. In: Junk WJ. (ed.) The Central Amazon Floodplain: Ecology of a Pulsing System. Berlin, Heidelberg, New York, Springer. p. 223-265.

Zhang L, Liu S, Sun P, et al. 2015. Consensus Forecasting of Species Distributions: The Effects of Niche Model Performance and Niche Properties. PLOS ONE 10: e0120056. doi: 10.1371/journal. pone. 0120056

Zhang Z, Xu S, Capinha C, Weterings R, Gao T. 2019. Using species distribution model to predict the impact of climate change on the potential distribution of Japanese whiting Sillago japonica. Ecological Indicators 104: 333-340. 